\title{
Innovative start-ups and policy initiatives
}

\author{
David Audretsch \\ O’Neill School of Environmental \& Public Affairs \\ Indiana University \\ Bloomington, IN 47401, USA \\ and \\ Department of Innovation Management and Entrepreneurship, \\ University of Klagenfurt, Austria \\ daudrets@indiana.edu
}

\author{
Alessandra Colombelli \\ Department of Management and Production Engineering (DIGEP) and \\ Entrepreneurship and Innovation Centre (EIC) \\ Politecnico di Torino \\ Corso Duca degli Abruzzi, 24 \\ 10129 Torino, Italy \\ alessandra.colombelli@polito.it \\ Luca Grilli \\ Department of Management, Economics, and Industrial Engineering \\ Politecnico di Milano \\ via R. Lambruschini 4b, 20156 \\ Milan, Italy \\ luca.grilli@polimi.it

\section{Tommaso Minola} \\ Center for Young and Family Enterprise and \\ Department of Management, Information and Production Engineering \\ University of Bergamo \\ via Pasubio 7b \\ 24044 Dalmine (BG), Italy \\ tommaso.minola@unibg.it

\section{Einar Rasmussen} \\ Nord University Business School \\ Bodø, Norway \\ einar.rasmussen@nord.no
}




\begin{abstract}
Innovative start-ups can create and shape new industries and generate considerable economic and societal impacts. Accordingly, a variety of policy initiatives are aimed at promoting the establishment, growth and impact of innovative start-ups. Designing such policies is a challenging task, because most start-ups fail. In addition, only a small share of those start-ups will ultimately prove to be innovative, and very few of those will eventually become high impact firms. Hence, effective policies require a better understanding of the processes by which innovative start-ups are formed, developed and create impact, as well as of the heterogeneous nature inherent to innovative start-ups along with their development trajectory. This article reviews 38 policy initiatives from around the world and classifies their approaches to the phenomenon of innovative start-ups. By relying on insights from the papers mentioned in this special issue, we develop a process framework by elaborating on (i) the antecedents of the creation of innovative start-ups, (ii) their founding characteristics, (iii) their behavior, and finally (iv) the outputs and impacts generated by them. Our framework highlights how policy initiatives, managerial issues and research approaches are conceptually different, depending on the specific stage of firm development. We conclude with implications for policy initiatives and further research.
\end{abstract}

Keywords: Entrepreneurship policy; entrepreneurial process; innovative start-up.

This is a pre-print version of the article published in Research Policy:

https://doi.org/10.1016/j.respol.2020.104027 


\section{Introduction}

Only a small share of start-ups is innovative, but those who are may play a particularly important role for economic development, technological advancement and societal impact (Autio et al., 2014; Audretsch et al., 2006; Baumol and Strom, 2007). All start-ups are associated with the liabilities of newness and smallness, which may lead to higher failure rates than those of more established firms. However, innovative start-ups have to face an additional liability of novelty as they introduce a new product, service or process onto the market, and this may negatively affect their survival rates. This is particularly true for start-ups that have a high-risk profile (Hyytinen et al., 2015).

Thus, innovative start-ups can be seen both as a distinct form of entrepreneurship and as a distinct mechanism for developing innovations. This dual nature of innovative start-ups poses a dilemma for policy makers because, on the one hand, these firms respond to entrepreneurship policies that seek to promote the creation of new ventures that survive and grow to generate jobs and economic development (Autio and Rannikko, 2016). On the other hand, innovative start-ups respond to innovation policies that seek to foster industrial competitiveness and societal renewal (e.g., European Commission, 2010; Grilli, 2014). This combination may be considered challenging because the most innovative start-ups with the highest (ex-ante) potential for growth and impact are often also the type of start-ups, which have the highest (ex-post) failure rate. Yet, in recent years, these firms have proved to be highly attractive targets for policy initiatives (Lerner, 2010), which means programs, schemes or plans that have been implemented with the specific aim of supporting the establishment or development of innovative start-ups.

Given the widely acknowledged importance of new venture creation on innovation, employment and economic growth, it is not surprising that innovative start-ups have played a central role in policy agendas and in the scholarly debate in recent years (Autio et al., 2014; Guerrero and Urbano, 2019). By mitigating the obstacles faced by entrepreneurs when starting new firms, policy makers predominately seek to promote the birth of start-ups. Unfortunately, the 
results of such policies have not always been particularly successful. Experience has shown that fostering the creation of start-ups without a tight scrutiny of their quality can result in a "bad public policy” (Shane, 2009; Colombelli et al., 2016). Furthermore, it is often argued that policymakers are required to shift their focus from implementing a mere collection of single policies for startups to designing a more holistic and interrelated “entrepreneurship policy” approach (Giraudo et al., 2019), capable of connecting the various dots, i.e. the institutions and infrastructures that determine to a great extent the ultimate outcomes of any policy intervention; and in doing so, being able to leverage on both “a national system of entrepreneurship” (Acs et al., 2014) and “entrepreneurial ecosystems” (Stam and van de Ven, 2019) to stimulate the innovative activity of new firms.

In this vein, governments have pursued and implemented specific national (and pan-national) policy actions, starting with the United States (US), in the year 2011, and quickly followed by several European and Asian countries, with the explicit aim of offering support to innovative startups (for an overview on Europe, see the European Digital Forum, 2016). Through national Startup Acts, innovative start-ups may receive a wide range of benefits, from simplified administrative requirements to tax reliefs, passing from flexible contracts for employees, to the possibility of raising capital through equity crowdfunding, accelerated liquidation procedures, and more. All of these measures are intended to facilitate business and innovation processes as catalysts for newfirm start-ups, and they are certainly (at least partly) responsible for the growing number of innovative start-ups created over a broad spectrum of contexts (Guerrero and Urbano, 2019).

However, there is a substantial heterogeneity of what scholars and policy makers mean by the term “innovative start-up”. There is a lack of systematic understanding of the different criteria and approaches used to define innovative start-ups and how these relate to the idiosyncrasies and policy rationale of firms. Research is needed to fill this gap and specifically to understand who innovative start-ups are and what they need in order to grow and thrive. There is still a need for refined 
theoretical approaches to firm creation and development in the case of innovative start-ups as well as research to support the design of effective policies.

The large and heterogeneous set of new national initiatives that promote innovative start-ups offers the opportunity for a number of reflections on the very nature of innovative entrepreneurship and the related policies. On the one hand, national strategies that support innovative start-ups are quite mixed and experimental, so that there is only a paucity of evidence on their effectiveness (see e.g., Giraudo et al., 2019; Hottenrott and Richstein, 2020 for some notable exceptions). On the other hand, these initiatives represent a playground where novel, theoretically- and empirically-sound scientific research can be stimulated on innovative start-ups. In fact, by developing new knowledge on the heterogeneity of definitions and conceptualizations of innovative start-ups, and by obtaining a better understanding of the idiosyncratic nature of such a typology of firm, a major theoretical advancement can be prompted on the processes and behaviors that make these firms unique.

This special issue on "Innovative start-ups and policy initiatives" has the aim of advancing the state-of-the-art in this area. After an open call for papers, we received 62 contributions. Following the regular Research Policy review process, 11 papers progressed to the stage that allowed them to be published in this issue. The papers provide a comprehensive collection of studies on different national, sectorial and institutional contexts and they span different levels of analysis and stages of firm development.

The present introductory paper has three objectives. First, by reviewing a sample of recent national policies adopted around the world to identify and target innovative start-ups, and by offering some evidence on their dissimilarities, this paper provides guidance on how to better compare and assess different policies (cf. Hottenrott and Richstein, 2020). Second, the paper outlines a conceptual process-based view of the innovative start-up phenomenon and discusses how the papers in the special issue substantiate the potential of a process-based approach to innovative start-ups and innovative entrepreneurship in general. Our framework enables a first 
step toward rethinking the heterogeneity of approaches regarding the innovative start-up phenomenon, from a problematic factor to an opportunity for research and practice. We discuss how scholars and policy makers can differently define, understand and support innovative startups, whether their focus is on the pre-entry, entry, or development phase of these firms. Finally, the paper offers guidance for future research and policy through an organized agenda.

\section{Innovative entrepreneurship policies around the world}

Entrepreneurship policies, and innovative entrepreneurship ones in particular, are widely used at different governmental levels throughout the world. Innovative entrepreneurship policy initiatives are predominantly implemented at the national level (Moss, 2011). Although no clear evidence has ever been produced about the effectiveness of innovative entrepreneurship policies across governmental bodies operating at different territorial levels, the national level allows for coherent and legitimate initiatives on tax, labor and financial markets (see the “National System of Entrepreneurship” concept and the related "Global Entrepreneurship and Development Index” one, e.g., Acs et al., 2014). Nevertheless, coordination among different policies is essential for their effectiveness (e.g., Giraudo et al., 2019), given the interdependencies and externalities that arise naturally across different comparts of an economic system (e.g., Cooper and John, 1988; Durlauf, 1993; Rodrik, 1996); thus, it should be noted that the effect of national policies on entrepreneurship can be reinforced or depressed by contemporaneous policies pursued at different territorial levels with the same or even different aims (see Grilli and Mariotti, 2006, for a discussion).

Recent studies have provided evidence on national policies regarding innovative entrepreneurship. The review by Guerrero and Urbano (2019) dealt with research on how to identify the link between entrepreneurship, innovation and policy frameworks. Autio et al. (2014), in their special issue, attempted to improve the understanding of the links between theory, practice and policy in innovative entrepreneurship. Overall, these works suggest a possible high degree of heterogeneity in the different definitions of innovative entrepreneurship and the related policies. In order to deepen our knowledge 
and provide some organized evidence on such a topic, we have synthesized certain national policies around the world. We first report the commonalities and differences in these recent policies and we then review how these policy initiatives define the concept of innovative start-ups.

\subsection{Identifying policy initiatives}

We used the GenGlobal "Startup Nations Atlas of Policies” (SNAP) database of policies, which is adopted throughout the world, and which we consulted in February 2019, to identify the policies. SNAP is a compendium of public sector policies and programs, and is part of the Global Entrepreneurship Network, in which several private and public organizations participate, including the European Commission and the Ewing Marion Kauffman Foundation. Our sample is the result of a filtering, using the database's own search engine, and a screening of each single policy initiative. First, we included only policies for start-ups and young scale-ups, thus removing generic policies for small and medium sized enterprises (SMEs) or for already established companies. Second, only recent and still operating policies were considered, as of Spring 2019. Third, only policies with a clear focus on innovative start-ups were retained. Using a broad conception of innovation, we screened the goals of each policy and included policies referring to one or more of the following dimensions: creation and implementation of a new idea in a new product or service; growth orientation; knowledge and/or technological intensity. Fourth, we eliminated policies with a substantial lack of information and those managed at the local or regional level (such as "Bristol is Open”, “Dublin Makes”, “Dublin Resident Concierge”). Policies that were part of larger and more complex industrial policies were considered only once, and only considering the part of the policy of interest here. This process allowed 38 policies to be identified.

After having identified the policies, we collected information about the programs from the SNAP database, from official websites and documents from each country, as well as from online articles in national newspapers and from the social network pages of the programs. E-mail contacts were also used to complement any insufficient online information. Table 1 reports the final list of 39 policies: 
9 cases are from Latin America, 12 from Asia and Oceania, 16 from Europe and 2 from Canada. The policies were then checked, according to UNCTAD (2012), to establish which of the five goals they pursue ("Fiscal policy and tax Incentives”, “Access to networks”, “Access to capital”, “Access to skills”, including entrepreneurship education, and “Immigration”), taking into account that a policy may have multiple objectives.

Insert Table 1 about here

\subsection{Descriptive evidence}

The different policies are classified and summarized in Table 1. Twelve of the policies are related to “Access to capital”, 18 pertain to “Access to skills”, 9 are related to "Immigration”, 25 to "Access to networks" and 12 to "Fiscal policy and tax incentive”. There is 1 policy focusing on all five goals, 10 focusing on three goals, 13 focusing on two goals, and the remaining focus on one single goal.

Eighteen of the policies aim at non-financial support. This support ranges from speeding up and easing administrative processes (such as "Ready in 4 months" in Malaysia and "Create company in 24 hours" in Argentina) to the finalization of product/service prototypes ("Grant-scheme for startups” in Croatia), attracting foreign entrepreneurs (“Rising Startup in Spain”, “Italia Startup Visa”), developing Ecosystems (actors, incubators, co-working spaces, such as “Station-F” in France, as well as networking and knowledge exchange, cooperation and connection, like “Superclusters” in Canada) to fostering enterprise education (working on both skills and motivations, such as "Digital Business Academy” in the UK). Eight policies are related to direct financial support, which can be divided into three categories: direct funding to firms over a firm’s lifecycle (seed, acceleration, expansion, internationalization); direct funding, under a co-investment regime with private institutions; indirect funding, such as tax reliefs for business angels and crowdfunding campaigns. Finally, 13 cases report a mix of financial and non-financial support measures. 
Very few policies have adopted a sectorial approach: some interesting examples are "Blue Growth” (Greece), which is aimed at developing new innovative ideas regarding the maritime sector, and the "Bahrain Regulatory Sandbox for Fintech Startups”. Only 1 policy (“Global Impact Visa” in New Zealand) offers a selective approach in terms of beneficiaries, as each year it provides 100 international and 20 local candidates with the opportunity of participating in a program that offers networking support.

Who are the governmental bodies that are responsible for the different policies? The most frequently represented entity is the "Ministry of industry/economic development” (or the equivalent), with 12 policies. Overall, about half of the cases report an official partnership (e.g., more Ministries or Chambers of Commerce) in the management of the policy initiative. In 5 cases, the entity in charge is the "Department of industry, innovation and science" (or the equivalent), like in "The Startup Ecosystem Development Program 2016-2021” in the Philippines. In 4 cases, the national initiative is managed by a pool of Ministries, as in the case of the "Startup Thailand National Program". Interestingly, in the case of the "K-Startup Grand Challenge” in South Korea, the managing entity is the Ministry of SMEs and Startups. In the immigration-oriented programs, like the case of “Global Impact Visa” in New Zealand, the program is managed by the Ministry of Immigration. In 5 cases, a dedicated national agency is responsible for the policy, such as in "Start -Up Chile", a program managed by the Corporación de Fomento de la Producción (CORFO). Finally, in another 5 cases, the national Taxation Office is in charge, such as in the "General Law of Commercial Companies" in Mexico.

\subsection{Focus on the definition of "Innovative Start-up"}

With so many different goal configurations and entities, it should not be surprising that there are also differences in the definition of an innovative start-up. We shed further light on this hereafter. The conceptualization and definition of innovative start-ups vary from nation to nation. We identified six different approaches, as reported in Column "Approach” in Table 1. First, the "New firms" 
approach comprises initiatives such as “Argentina's Entrepreneurs Act” and does not require the supported firm to be innovative, despite mentioning the aim of supporting innovative entrepreneurship. The underlying (Schumpeterian) assumption is that entrepreneurship in general is an intrinsic source of dynamism that implies innovation.

Second, the "Self-declaration" approach includes programs in which innovativeness is a requirement for support, and the responsibility of proof rests with the applicant firm. This process is done through self-declarations in which the nature and the innovative character of the entrepreneurial project are stated, which are then verified by the program operator or an independent verification service. One example is the "Social Innovation Lab" in Taiwan. The verification processes and criteria vary to a great extent and, overall, there is a lack of detail on this (crucial) aspect.

A third group of programs considers firms innovative if they belong to certain sectors, and this is therefore labeled the "Sector specific" approach. These sectors are typically high-tech sectors (Information Technology, as in the case of Hong Kong) or sectors that are strategically relevant for the Nation (such as the "GET-Up” program in Singapore).

Fourth, some policies are targeted to growth-oriented start-ups (and not necessarily directly to innovative start-ups), assuming that, in the current global and hypercompetitive context, growth orientation or scalability are almost synonymous with innovation. We refer to this as the "growthoriented” approach, and it is exemplified by the "Global acceleration Program” in Malaysia.

Fifth, the innovativeness of the start-up in some programs is (like in the second case) self-declared by the firm and verified by the national government. However, this attribute is not specifically related to the project for which the firm is asking for public assistance, but rather to a general certification of the firm itself, a sort of status, that can be used for specific support program applications, as well as for other more generic benefits, such as tax reductions or hiring facilitations. This "Certification” approach includes the “Innovative SMEs” program in Cyprus and the “Italian Startup Act”. 
In the sixth ("Partner specific") approach, affiliation with certain partners is used to identify innovative target firms, like in "Entrepreneurs Clubs Argentina”, where an innovative start-up is basically any firm located in a co-working space.

In addition to the six categories mentioned above, there is a further subset of policies that target innovative start-ups indirectly. Examples of such policies are tax incentives granted to early stage investors who invest in innovative start-ups (e.g., "Early stage investors” in Australia), support for graduates at all levels of education (e.g., "HITSA2020” in Estonia) and support for innovative entrepreneurial ecosystems (including firms) (e.g., “Entrepreneurial Cities Argentina”). Moreover, the different approaches are sometimes combined, such as in the case of the "Grant-scheme for startups” in Croatia, which targets innovation-driven start-ups ("Self-declaration” approach) that have the ambition to scale their enterprise on international markets (“Growth-oriented” approach); or "Startup India”, where innovativeness is granted upon verification of the self-declaration of the possession of intellectual property rights (“Self-declaration” approach) or upon endorsement by an external partner ("Partner-specific" approach), since the start-up can only gain the status of being innovative if it presents a recommendation by either a certified incubator, a private investors' networks or a governmental agency.

Moreover, it should be noted that it was not possible to infer the type of approach for all 38 policies, due to a lack of information (7 cases reported as "N/A" in Table 1). Finally, although all the programs target start-ups, some are exclusively dedicated to new firms, whereas others also support any SME, such as "Enisa participative Loans” in Spain.

Taken together, it is evident that these policy approaches are heterogeneous and rather fragmented. They differ over several important dimensions, including the target firms and the criteria related to identifying start-ups, their objectives and goals, and the tools designed to achieve these goals. The policy approaches span from being backward-oriented (i.e. looking at the founding characteristics or track record) to forward-oriented (i.e. looking at the declared project goals, ambitions or future prospects). Furthermore, some policies focus on the firm and its internal resources, while others target 
the external environment in which the firm operates, such as the sector, the location, or the network of external relationships. Some explicitly focus on innovation, for example by certifying the innovative activity of a firm within a limited domain and timeframe, while others rely on more permanent status-based definitions. Although some policies target individuals (i.e. the entrepreneur or the founding team), most target firms (nascent or recently established). Finally, some offer formal ex-ante, transparent, automatic criteria for the definition of what constitutes innovativeness, while others do not.

Such heterogeneity can lead to both theoretical and practical problems, in terms of comparability and generalizability, respectively. On the one hand, the fragmented approaches limit the understanding of what characteristics, behaviors and outcomes distinguish different types of innovative start-ups. Different bodies of evidence on the functioning of these firms are difficult to compare, and this prevents the elaboration of a coherent conceptual effort on the different mechanisms and processes that can prompt the setting up of innovative start-ups. On the other hand, this heterogeneity makes it difficult to aggregate experiences from different programs and countries, and therefore to derive generalized insights to improve the effectiveness of such policies.

\section{A process framework for innovative start-ups}

The heterogeneity of policy initiatives for innovative start-ups is evident from the different definitions used to identify innovative start-ups and from the different phases of firm development targeted by these policies. As a basis for discussing innovative start-ups, in relation to policy initiatives, this section presents a process framework that highlights differences in the conceptualization and the role of policy initiatives in different phases. The framework elaborates how policy initiatives can influence the antecedents that are conducive to the creation of innovative startups, their founding characteristics, their behaviors, and, finally, the outputs and impacts they generate. Moreover, we use the framework to position the papers in this special issue and show how they 
contribute to the literature on policy initiatives for innovative start-ups (see Table 2 for an overview of the papers).

Insert Table 2 about here

The entrepreneurial process is highly uncertain (McMullen and Shepherd, 2006), thus making static definitions of innovative start-ups incomplete. Innovations can emerge and develop in different forms and across different stages of venture development, and any conclusive measure of what constitutes an "innovative start-up" can hence only be made ex-post, after the firm has introduced an innovation onto the market. For instance, defining innovative start-ups on the basis of their sectors (e.g., NACE or NAICS codes) or their founding characteristics (e.g., academic founders) may run the risk of including firms that ultimately turn out not to be innovative (false positives) and excluding firms that eventually become highly innovative (false negatives). Many of the quantity-based measures of start-up activity are not well suited as proxies for innovative entrepreneurship (Henrekson and Sanandaji, 2019). Hence, there is a need to extend the view of innovative start-ups beyond the nascent phase in order to incorporate long-term outcomes and impacts. A process framework can help conceptualize the different stages and provide a more consistent basis for both the research on innovative start-ups and for the design and implementation of policy initiatives.

A common way of conceptualizing processes in the innovation and entrepreneurship literature is by using stage models that prescribe a predictable process (Kazanjian, 1988; Fisher et al., 2016; Vohora et al., 2004). Stage models provide frameworks that are simple, intuitive and easy to communicate. Because they can conceptually distinguish between stages and their specific challenges, stage models are ideal for classifying and assessing different approaches on innovative start-ups and policy consequences. However, stage models do not give explanations on how and why processes proceed from one stage to the next (Rasmussen, 2011). Hence, they should be 
supplemented with other perspectives in order to be able to account for the multilevel and dynamic interactions that take place as the process proceeds.

Our framework focuses on firm processes and attributes, and specifies the characteristics of innovative start-ups and their relationship with policy initiatives. In doing so, we also acknowledge the importance of context for innovative start-ups, along the different categories suggested by Autio et al. (2014); we specifically focus on industry and on technological, organizational, institutional and policy, and social contexts.

Table 3 provides an overview of how innovative start-ups can be conceptualized at each of the four stages we identify, how they can be empirically investigated and how the associated policy initiatives can be analyzed. Reference to studies from this special issue that have provided insights into the development of the framework are also provided, over several dimensions, such as the overarching question, the typical theoretical perspectives, examples of policy categories and others, which we explain in detail hereafter.

Insert Table 3 about here

\subsection{Antecedents of innovative start-ups: Where do innovative start-ups come from?}

The first stage is related to classifying entrepreneurial ventures as innovative, and designing support to them, prior to their formation stage. The assumption here is that innovative start-ups have a certain origin and are established upon specific antecedents that influence their development and outcome. It is obviously not possible to target a new venture before it is created, but policies can create the necessary conditions to increase the likelihood of innovative start-ups being created. A prevailing view is that start-ups are formed at the intersection between enterprising individuals and entrepreneurial opportunities (Shane, 2003). Hence, policy initiatives may target individuals who are likely to become involved in the creation of innovative new ventures (e.g., training programs, support 
for effective entrepreneurial team formation) and the potential sources of innovative opportunities for innovative start-ups (e.g., through IPR legislation, R\&D funding). [579] investigate the long-term business and innovation potential of subsidized start-ups out of unemployment in Germany and compare them with a group of regular founders who started from non-unemployment and did not receive any public subsidies. They find that unemployed individuals who receive start-up subsidies have a significantly lower innovation performance than a control group of regular founders without any subsidy. Hence, such subsidies may be an appropriate policy initiative for generating employment, but less so for spurring innovation.

It is well established that people with more education and high levels of human capital are more likely to found innovative start-ups (Protogerou et al., 2017). In this issue, [545] study the role of founder occupational background for the performance of biomedicine start-ups, a sector where firms are systematically engaged in the production and commercialization of new technologies. By comparing firms with academic versus non-academic founders, the authors observe differences in the likelihood and hazard of achieving a liquidity event. Non-academic start-ups are more likely to achieve an IPO or acquisition, but there are also variations among different types of academic startups (e.g., student-, faculty- and prominent-scientist-based). The paper suggests that a firm's comparative advantage emanates from knowledge conversion capability as indicated by the (academic) founder's occupational background. Lastly, as indicated by psychological and cognitive approaches to entrepreneurship, the occupational background can also influence the entrepreneur's motivations and attitudes (Lam, 2011).

Technological changes can be an important source of new opportunities for innovative start-ups (e.g., biotech, internet, digitalization, sustainability) (Audretsch and Keilbach, 2008). In line with the knowledge spillover theory, research organizations and corporations are important contexts for the creation of innovative start-ups (e.g., Minola et al., 2019; Klepper and Sleeper, 2005). Because of their access to talent and knowledge, universities are seen as seedbeds for innovative start-ups, and are therefore a particularly fertile context for implementing policy initiatives to increase 
entrepreneurial activity. A seminal example is the Bayh-Dole Act of 1980 in the US and the corresponding legislative changes made in many countries to strengthen the commercialization of university research (Grimaldi et al., 2011). This act also spurred the establishment of such infrastructures as technology transfer offices and other university policies (Rasmussen et al., 2014). Other examples are related to financial support and competence development for academic entrepreneurship (Croce et al., 2014; Kochenkova et al., 2016).

Several papers in this special issue examine the academic entrepreneurship context. [588] show how supportive university regulations at the pre-formation stage can lead to the creation of more academic spin-offs, but also that this effect is contingent on the characteristics of the university departments, the specific design of the regulation, and the temporal lag between the regulatory intervention and the measurement of effects. However, initiatives to increase the number of new ventures may come at the expense of the quality of these firms (Fini et al., 2017).

Technological changes also have important sector specific dynamics, and sectors can be sources of technological changes (Autio et al., 2014). Other contextual influences that matter for the creation of innovative start-ups are the industry entry conditions (Aldrich and Fiol, 1994), informal institutions (e.g., social norms, perceptions of legitimacy and social desirability, cf. Autio et al., 2013) as well as formal ones (e.g., regulation of entry, see Branstetter et al., 2014; institutional barriers to growth, Eesley, 2016; bankruptcy regulations, Eberhart et al., 2017), and social contacts (e.g., family and peers, cf. Hahn et al., 2019a). In order to examine the responses of start-ups to regulatory constraints, [610] focus on the drone application industry, where regulatory constraints dynamically affect the potential of an emerging technology to a great extent.

\subsection{Founding characteristics of innovative start-ups: What makes a start-up innovative?}

A common way of defining innovative start-ups is to refer to their founding characteristics; this view implies that it is a set of certain characteristics, attributes and resources - which act as an imprint for the new firm - that characterizes its innovativeness (Heirman and Clarysse, 2004). Examples of 
policies that follow this approach are: direct and indirect financial support, technology transfer initiatives, and attraction of human capital (e.g., by means of foreign entrepreneurs). To do so, many policies are selective in what types of firms they support, according to observable criteria (e.g., sector, founder's characteristics, or technological assets) or subjective information (e.g., self-reported innovativeness) at inception. For example, as already emphasized, [579] illustrate how founder characteristics, such as occupational status or background, can influence the performance of start-ups by specifically constraining access to capital and business strategies.

By focusing on VC-backed academic spin-offs originating from British universities to analyze how different alliance types impact the likelihood of realizing a liquidity event, [583] show that prior market experience in the founding team can mitigate the liabilities of technology-search alliances. The findings show that market-search alliances increase the chances of realizing a liquidity event, whereas technology-search alliances reduce these chances, although this effect is mitigated when the spin-off has a founding team with prior market experience. In terms of policy, the paper indicates that these firms are the most attractive and have the greatest economic impact potential, and it encourages their collaboration with incumbents, even after the liquidity event, to enhance their strategic market development.

With the aim of analyzing to what extent innovative start-ups take advantage of policy support to implement innovation appropriation mechanisms, [735] focus on a sample of Italian start-ups that are defined as "innovative" upon the fulfillment of one of the following criteria: a high level of R\&D, highly qualified human capital, possession of intellectual property rights. The analyses show how the use of financial policy measures is associated with both formal appropriation mechanisms (e.g., intellectual property rights) and informal ones (e.g., secrecy, lead time, access to complementary assets), while labor policy measures are only related to formal ones. In terms of policy, an interesting implication of the paper is that, in order to prompt an appropriability strategy in innovative start-ups, the introduction of governmental guarantees on bank loans appears to be a promising instrument. 
Apart from human capital (individual and a team’s) and knowledge intensity (like R\&D and patents), the founding characteristics can also be related to the goals of the entrepreneurs or ventures. It is well known that entrepreneurs pursue a variety of different individual goals. Lam (2011) showed that scientists' engagement in commercialization activities, such as start-ups, is driven by a diverse set of motives related to financial reward, resources for research, and interest in problem solving. An increasing number of contributions have recently emphasized the importance of non-financial goals, such as the desire to have a social impact (Wilson and Post 2013; Lumpkin et al. 2013; Chell 2007). Other studies have looked at the identities of entrepreneurs, distinguishing between distinct types of founder identities - Darwinians, Communitarians and Missionaries - that imprint the subsequent behavior and outcomes of the firm (Fauchart and Gruber 2011). In the context of technology startups, the firm's identity is considered important for resource acquisition, but also adaptable to the expectations of key resource holders at different stages of venture development (Fischer et al., 2016). In these processes, the composition and dynamics of a team are very important as they affect cohesion and social exchange (Ensley and Hmieleski, 2005) and regulate how imprinted characteristics define the innovative orientation (Hahn et al., 2019b) and growth performance (Grilli et al., 2020) of a firm.

[795] show that those start-ups that pursue environmental value creation tend to be more innovative than those that seek economic value creation. 'Greener start-ups' are more likely to engage in product and process innovations, although this choice depends on the environmental regulations in force. These findings suggest a fundamental difference in how economic value creation (private wealth generation, i.e. self-regarding interest) and environmental value creation (environmental gains for society, i.e. other-regarding interest) influences the identification and exploitation of entrepreneurial opportunities.

\subsection{Behavior of innovative start-ups: What does an innovative start-up do (differently)?}

Innovative start-ups can be differentiated not only on the basis of their founding characteristics, but also by their post-founding behavior. The assumption is that they can be recognized as innovative 
because they engage in certain decision-making initiatives. An innovative start-up may become less innovative over time, or a non-innovative start-up may start innovating. This highlights the challenge of defining innovative start-ups, because this definition needs to reflect both what characterizes an innovative firm and at what "stage" in the firm's development process this should be measured. Hence, being an innovative start-up is not a stable characteristic, but a state that can be influenced by external actors. Here, policy initiatives can address shortages of innovative start-ups by providing financial resources (e.g., innovation grants and financial measures, whether direct or indirect) as well as social and human capital (e.g., incubators, advisory and coaching, removal of labor market rigidities).

[604] delve into differences in firm behavior by comparing older and younger innovative small firms to unpack the liabilities of newness and smallness. The findings show that R\&D investments make a lower contribution to the innovation performance of new ventures than older small firms. In contrast, external knowledge sourcing makes a greater contribution to the innovation performance of new small firms than of older ones, but only in high-tech settings. No support is offered to show a differentiating effect of $R \& D$ subsidies in new versus established small firms. This study indicates that innovative start-ups face a liability of newness that would be better remedied by policies that stimulate external knowledge sourcing than those that simulate internal R\&D.

Moreover, the definition of innovativeness can be decisive in determining which firms are targeted or selected for policy initiatives, as discussed by [730], who look at the provision of advisory services offered to innovative start-ups by ad-hoc specialized public bodies. While the program is found to have a generally positive effect on innovation performance, the findings emphasize the role of collaborative learning between government sponsored advisors and innovative start-ups. The paper identifies innovative start-ups as those that prioritize innovation and learning behavior, regardless of their founding conditions, thus emphasizing a “behavioral” approach. In terms of policy implications, the paper indicates the importance of formal prioritization of innovation-based evaluation criteria for programs that want to boost innovation outcomes. Given the key role on performance played by the 
participants' willingness to learn collaboratively from their advisors by socializing their growth objectives, the paper also implies that such an attitude should be part of an effective ex-ante evaluation of target firms.

A key part of the development of innovative start-ups is related to the partnerships and collaborations that these firms engage in during their development process. Policy initiatives that seek to connect start-ups with external resource providers are widely used (incubators, accelerators, investors, corporate partners, etc.). When analyzing the support provided by business incubators, the literature on organizational sponsorship refers to bridging and buffering mechanisms (Amezcua et al., 2013).

[591] investigate the design of government venture capital as a policy instrument to remedy the problem of accessing financing among young innovative firms. This type of financing is a common example of a hands-on approach, where policy makers seek to provide resources directly to selected firms, generally those with growth and innovation potential. The study finds evidence that government venture capital is less successful in economically lagging regions, but those that build up industry-specific expertise and those who previously co-invested with private investors are more likely to bridge the equity gap. In doing so, similarly to other studies (e.g., Grilli and Murtinu, 2014), but from a novel perspective and adding new insights, the analysis of the authors confirms the idea that a strict collaboration between public and private actors is needed in venture capital (VC) investment if the public wants to produce sizeable effects on the investees.

[583] analyze the behavior of VC-backed academic spin-offs and how the types of alliances they engage in influence their performance. This study illustrates the importance of market linkages for these firms, which already have strong technological linkages. By using IPO and trade sales as outcome measures, this study uncovers a hitherto scarcely investigated pre-deal process (Welch et al., 2019), and thereby provides a valuable understanding of the implications for the design of policy initiatives. 
The context of the firm is likely to influence its innovation performance. [596] investigate how related and unrelated industry variety (i.e. the variety of co-located firms within industries that share knowledge complementarities among products vs the variety of co-located firms between industries that do not share knowledge complementarities among products) at a start-up's home location influence performance, in terms of the firm's internationalization. The findings show that the related industry variety is positively associated with exporting likelihood and persistence, and even more so when the employees have international experience. By contrast, unrelated industry variety is positively associated with exporting likelihood and persistence, albeit only when employees possess technological knowledge.

[610] find that the variation in start-ups' responses is instigated by their temporal orientation. Startups pursuing applications targeted at present markets or future potential markets treat regulations as exogenous. Start-ups that pursue market applications that bridge current and future potential markets are instead more likely to treat regulation as endogenous. This has important implications for how government regulations can influence innovative start-ups or innovation activity in start-ups.

From a theoretical perspective, although resource-based ([735]), imprinting (Simsek et al., 2015; Hahn et al., 2019b) and identity (Jain et al., 2009) approaches are also helpful in this phase, the focus on decision-making and behavior makes the behavioral theory (Cyert and March, 1963) particularly compelling for this stage, as it determines such aspects as knowledge and technology searching and ambidexterity (Koryak et al., 2018). In terms of context, apart from institutional and industry effects, at this stage, it is possible to recognize the impact of the organizational context (culture, practices, experience, knowledge and skill, see Autio et al., 2014; Minola et al., 2019) and the social milieu (trading partners, financiers, and incumbent firms, cf. Agarwal and Shah, 2014; Stam and van de Ven, 2019).

3.4: Outputs and impacts of innovative start-ups: What does an innovative start-up achieve? 
Innovative start-ups can be assessed on the basis of how successful they are in bringing new inventions to application, and they are often acclaimed for their contribution to economic growth, job creation and regional economic development (Audretsch et al., 2006; Baumol and Strom, 2007; Audretsch and Keilbach, 2008). This statement assumes that the defining characteristic of innovative start-ups is their achievement of certain outcomes and certain impacts. However, the outcome distribution of innovative start-ups is highly skewed, where a few outliers account for the majority of quantifiable contributions. Despite the great interest of both academics and policy makers in startups reaching IPO or growing into a sizable firm, particularly those that become 'unicorns', these are extremely rare events (Aldrich and Ruef, 2018).

In this issue, [545] and [583] use a highly relevant output measure of innovative start-ups by looking at liquidity events, in terms of IPOs and trade sales. These are preferred exit options for the investors, but trade sales and IPOs may also provide start-ups with access to resources that can help scale their ventures and increase the overall impact of the technologies. Through trade sales, an innovative technology often departs from the original start-up and becomes the property of the acquiring organization. This exemplifies how innovative start-ups can create impact though pathways other than organic growth, but also illustrates the challenge of obtaining reliable data on the longterm impacts generated by these firms.

Entrepreneurship and new ventures have recently been seen as potential mechanisms for tackling societal grand challenges (Markman et al., 2019). Hence, innovative start-ups may lead to outcomes and impacts that go beyond their direct and indirect economic performance. For instance, innovative start-ups are an important mechanism for the commercialization of scientific research and thereby impact society in substantial ways (Fini et al., 2018). Several difficulties arise when measuring the social impacts of new ventures (Rawhouser et al., 2019), thus making it challenging to design effective policies aimed at such impacts. A start-up may provide innovative outcomes and impacts that go beyond the expectations foreseen when the firm was first established. Moreover, firms may provide impacts that are difficult to measure at a firm level, such as knowledge and technology 
transfer to their customers (Autio, 1997) or improved long-term labor market outcomes for participants, as discussed in [579].

The shift from the dominant market failure rationale for government policies to more mission oriented policies has opened the way toward new discussions on what type of firms should be prioritized. One example is involving innovative start-ups in co-development and public procurement (van Winden and Carvalho, 2019). Another example is that of policies which promote sustainability transitions, where the aim is not only to stimulate the economic system, but also to spur wider changes in socio-technical systems (Kivimaa and Kern, 2016). [795] illustrate the heterogeneity of the goals of start-ups and how the goal of environmental value creation influences innovativeness.

\section{Implications for research and policy}

Entrepreneurship and innovation are two areas that have garnered a great deal of attention of policymakers on their own. When the two are combined, the interest is magnified. On the one hand, innovative start-ups are reputed to be the firms that suffer the most from potential market imperfections in key areas, such as financing, labor and access to complementary assets. On the other hand, the economic and societal impacts generated by some of these firms are substantial. Accordingly, innovative start-ups are the main target of many policy interventions. As clearly shown in this special issue, targeting innovative start-ups from both policy and academic perspectives is challenging and requires particular attention to the different needs of firms at the different stages of firm development. Some of the challenges related to benchmarking and knowledge accumulation, which are relevant for the designing of policy initiatives, clearly depend on the heterogeneity of definitions, which cannot (and probably should not) be resolved.

Innovative start-ups do in fact exist, but it is only possible to actually realize what an innovative start-up is and does when the actual realization of its innovative strategies is observed over a wide array of dimensions, including product offer, process, organization, marketing, IPR management, etc. The problem, from a policy perspective, is that this approach is fallacious and intrinsically unfeasible, 
because taking no action ex-ante by the policy maker brings with itself the risk that many potential good prospects could never appear in markets, while an ex-post action simply risks being translated into “cherry-picking” and only generating deadweight losses (Dosi et al., 2006) and Matthew effects (Merton, 1968). Thus, what can the policy makers do to overcome these issues, and what can our special issue tell us about this conundrum?

Considering the papers in this special issue, it is first possible to affirm that, despite the empirical vagueness of the operationalization of the concept of what constitutes an "innovative start-up", the policy puzzle does not appear to pose a “Catch-22” problem. Overall, it has been shown that, in each specific and limited national context, making (even) a (national-contextual) choice of what constitutes an innovative start-up (whether this may have a general validity or not), and doing something for this chosen target, appears to produce positive effects, at least in terms of the recipients of public support. However, the counterfactual is difficult to assess. Although it is difficult to know what would have happened if a policy maker had pursued different choices from those actually made, the contributions of this special issue, taken as a whole, cast some doubts on the capability of pan-national public organisms to draw the exact boundaries of an innovative start-up as a policy target that is valid in all geographical, institutional and industrial contexts (see, for example, the European Commission's definition of a young innovative company, e.g., Czarnitzki and Delanote, 2013).

We suggest that the positive impact of policies in this domain may also depend on the fact that, while ideally and conceptually targeting "innovative start-ups”, these policies in fact target different types of start-ups. To put it simply, when it comes to an innovative entrepreneurship policy, it seems that the usual "one size does not fit all” mantra, which means that one single policy cannot benefit all firms, should be complemented by the equally important formula "one definition (of innovative startup) probably does not fit all (contexts)”. Furthermore, we also believe that this added complexity calls for research endeavors that are capable of taking a more holistic view, not only analyzing the effects of single policies from a general economic equilibrium perspective, but assessing the impact of the policy on the entrepreneurial ecosystem (Stam and van de Ven, 2019) in a broader sense and 
including more than just the supported and targeted firms. Innovative start-ups are part of a start-up incubation ecosystem consisting of interdependent actors and factors that interact in a system to provide a nurturing environment for the creation and successful development of start-ups (Novotny et al., 2020). Hence, the effect of single policies may not only be related to the specific firms supported, but also contribute to a well-functioning ecosystem for innovative start-ups.

Furthermore, one of the main contribution that here we offer is a stage-based framework on innovative start-ups. Stage approaches have already been applied in research on innovative entrepreneurship. For example, Malerba and McKelvey (2018) offered a stylized process framework of knowledge-intensive innovative entrepreneurship that recognizes the complexity, dynamics and actors' multilevel relationships, which yield a performance and market structure. Block et al. (2017) referred to the antecedents, behaviors and outcomes of innovative entrepreneurship. Our approach is different, because we do not assume that innovative start-ups belong to a homogenous category that manifests itself through different proxies or indicators along the whole entrepreneurial process. We instead recognize that the very category of innovative start-ups is actually composed of heterogeneous types of firms that might or might not present elements (or proxies) of innovativeness throughout all the different phases of their development. Therefore, in our approach, what should characterize a firm as innovative in a given phase is simply the coherence with certain criteria that are specific to that phase. Such an approach also allows, for example, firms that do not originate from universities or do not come from high-tech sectors, but which end up impacting the technological competition by successfully scaling up (e.g., through effectively business modeling), to be classified as innovative firms.

Our discussion and the empirical papers in this special issue suggest several implications. On the one hand, as already indicated, the role of public policies and support in innovative start-ups depends on the phase of development. Therefore, when designing a policy agenda in this domain, stakeholders should reflect on: (a) what objective function they want to maximize (e.g., cost effectiveness, or comprehensiveness of beneficiaries, rather than nurturing a few innovation champions or reaching a 
critical mass) and which priorities they want to pursue (e.g., stimulating the offering of rather than the demand for innovative start-ups); (b) whether their portfolio of policies is balanced and which complementary initiatives should be launched simultaneously (e.g., a training program and ecosystem-centered subsidies). Moreover, there is also a need for a better understanding of the linkages between different phases of development; for example, how do different motivations and founding resources influence the types of impacts generated by innovative start-ups? Under what conditions is there continuity and consistence in fulfilling the "innovative” status across stages?

On the other hand, this special issue also offers an agenda for future research and policy. Table 4 provides a non-exhaustive summary of questions that have been derived from the papers and reflections of this special issue.

Insert Table 4 about here

In line with the spirit of this special issue, each of these directions can be read from both a research and a policy perspective, as they were thought up to stimulate the interest of both academics and policy makers. The questions are organized according to two key dimensions: the process framework developed in Section 3 (columns) and the focal dimensions of the Development process, Contextual influence and Methodological and measurement issues (rows). The "Development process" dimension raises questions at the core of the four innovative start-up conceptualizations and puts emphasis on the types of firms (e.g., student start-ups), actors (e.g., family and innovation brokers) and behaviors (e.g., internationalization and open innovation) that have so far received very little attention. The "Contextual influence” dimension suggests possible questions that have emerged from taking into account the different contextual dimensions suggested by Autio et al. (2014) (e.g., technological, organizational, social, etc.) and the formal institution ones in particular (e.g., labor market policies and regulatory constraints). The "Methodological and measurement issues" 
dimension unfolds ideas that have been derived from the empirical aspects of the papers in the special issue or challenges that might open up experimental or in-depth qualitative research designs.

\section{Conclusion}

Given the widely acknowledged importance of new venture creation to innovation, employment and economic growth, in recent years a variety of policy initiatives aiming at promoting the establishment, growth and impact of innovative start-ups have been issued worldwide. Yet, there is substantial heterogeneity in terms of criteria and approaches used to define innovative start-ups and lack of systematic understanding of how these relate to firm's idiosyncrasies and policy rationale. This evidence calls for refined theoretical approaches of firm creation and development in the case of innovative start-ups as well as research to support the design of effective policies.

This introductory article contributes to a better understanding of the process by which innovative start-ups are formed, developed and create impact and of the heterogeneous nature inherent in innovative start-ups along with their development trajectory. By reviewing 38 policy initiatives around the world, we unearth the heterogeneity of policy initiatives for innovative start-ups. By relying on insights from the papers in this special issue, we develop a process framework, which elaborates on how policy initiatives can influence the antecedents conducive to the creation of innovative start-ups, their founding characteristics, their behavior, and finally the outputs and impacts they generate. The framework highlights how policy initiatives, managerial issues and research approaches are conceptually different, depending on the specific stage of firm development. The process model also allows systematizing the implications for policy initiatives and an agenda for future research.

\section{Acknowledgements}

We are extremely grateful to Martin Kenney for all the support and insights offered us throughout the journey of this special issue. We would also like to thank Daniel Agyare and the students of the 
“Strategic Management Lab” (M.E. MSc, University of Bergamo, 2018-19 academic year) for their

support in the activity described in Section 2.1.

\section{References}

Acs, Z. J., Autio, E., \& Szerb, L. (2014). National systems of entrepreneurship: Measurement issues and policy implications. Research Policy, 43(3), 476-494.

Agarwal, R., \& Shah, S. K. (2014). Knowledge sources of entrepreneurship: Firm formation by academic, user and employee innovators. Research Policy, 43(7), 1109-1133.

Aldrich, H. E., \& Fiol, C. M. (1994). Fools rush in? The institutional context of industry creation. Academy of Management Review, 19(4), 645-670.

Aldrich, H. E., \& Ruef, M. (2018). Unicorns, gazelles, and other distractions on the way to understanding real entrepreneurship in the United States. Academy of Management Perspectives, 32(4), 458-472.

Amezcua, A. S., Grimes, M. G., Bradley, S. W., \& Wiklund, J. (2013). Organizational sponsorship and founding environments: A contingency view on the survival of business-incubated firms, 1994-2007. Academy of Management Journal, 56(6), 1628-1654.

Audretsch, D. B., Keilbach, M. C., \& Lehmann, E. E. (2006). Entrepreneurship and economic growth. Oxford University Press.

Audretsch, D. B., \& Keilbach, M. (2008). Resolving the knowledge paradox: Knowledge-spillover entrepreneurship and economic growth. Research Policy, 37(10), 1697-1705.

Autio, E. (1997). New, technology-based firms in innovation networks symplectic and generative impacts. Research policy, 26(3), 263-281.

Autio, E., Pathak, S., \& Wennberg, K. (2013). Consequences of cultural practices for entre- preneurial behaviors. Journal of International Business Studies, 44(4), 334-362.

Autio, E., Kenney, M., Mustar, P., Siegel, D., \& Wright, M. (2014). Entrepreneurial innovation: The importance of context. Research Policy, 43(7), 1097-1108.

Autio, E., \& Rannikko, H. (2016). Retaining winners: Can policy boost high-growth entrepreneurship? Research Policy, 45(1), 42-55.

Baldwin, C., \& Von Hippel, E. (2011). Modeling a paradigm shift: From producer innovation to user and open collaborative innovation. Organization science, 22(6), 1399-1417.

Baumol, W. J., \& Strom, R. J. (2007). Entrepreneurship and economic growth. Strategic Entrepreneurship Journal, 1(3-4), 233-237.

Bertoni, Fabio, Massimo G. Colombo, and Luca Grilli (2011). Venture capital financing and the growth of high-tech start-ups: Disentangling treatment from selection effects. Research Policy, 40(7), 1028-1043.

Block, J. H., Fisch, C. O., \& Van Praag, M. (2017). The Schumpeterian entrepreneur: A review of the empirical evidence on the antecedents, behaviour and consequences of innovative entrepreneurship. Industry and Innovation, 24(1), 61-95.

Branstetter, L., Lima, F., Taylor, L. J., \& Venâncio, A. (2014). Do entry regulations deter entrepreneurship and job creation? Evidence from recent reforms in Portugal. The Economic Journal, 124(577), 805-832.

Chell, E. (2007). Social enterprise and entrepreneurship: towards a convergent theory of the entrepreneurial process. International Small Business Journal, 25, pp. 5-26.

Clarysse, B., Wright, M., Bruneel, J., \& Mahajan, A. (2014). Creating value in ecosystems: Crossing the chasm between knowledge and business ecosystems. Research Policy, 43(7), 1164-1176.

Colombelli, A., Krafft, J. and Vivarelli, M., (2016), To be born is not enough: The key role of innovative startups. Small Business Economics, 47, 277-291. 
Colombo, M. G., Doganova, L., Piva, E., D’Adda, D., \& Mustar, P. (2015). Hybrid alliances and radical innovation: the performance implications of integrating exploration and exploitation. The Journal of Technology Transfer, 40(4), 696-722.

Cooper, R., \& John, A. (1988). Coordinating coordination failures in Keynesian models. The Quarterly Journal of Economics, 103(3), 441-463.

Croce, A., Grilli, L., \& Murtinu, S. (2014). Venture capital enters academia: An analysis of university-managed funds. The Journal of Technology Transfer, 39(5), 688-715.

Cyert, R. M., \& March, J.G. (1963). A behavioral theory of the firm. Englewood Cliffs, NJ, 2(4), 169187.

Czarnitzki, D., \& Delanote, J. (2013). Young innovative companies: the new high-growth firms?. Industrial and Corporate Change, 22(5), 1315-1340.

Dosi, G., Marengo, L., \& Pasquali, C. (2006). How much should society fuel the greed of innovators?: On the relations between appropriability, opportunities and rates of innovation. Research Policy, 35(8), 1110-1121.

Durlauf, S. N. (1993). Nonergodic economic growth. The Review of Economic Studies, 60(2), 349366.

Duflo, E. (2017). Richard T. Ely lecture: The economist as plumber. American Economic Review, 107(5), 1-26.

Eberhart, R. N., Eesley, C. E., \& Eisenhardt, K. M. (2017). Failure is an option: Institutional change, entrepreneurial risk, and new firm growth. Organization Science, 28(1), 93-112.

Eesley, C. (2016). Institutional barriers to growth: Entrepreneurship, human capital and institutional change. Organization Science, 27(5), 1290-1306.

Ensley, M. D., \& Hmieleski, K. M. (2005). A comparative study of new venture top management team composition, dynamics and performance between university-based and independent start-ups. Research policy, 34(7), 1091-1105.

European Commission. 2010. Europe 2020: A Strategy for Smart, Sustainable and Inclusive Growth. Communication from the Commission, Brussels, 3.3.2010.

European Digital Forum (2016). The 2016 Startup Nation Scoreboard (London, U.K.).

Fauchart, E., \& Gruber, M. (2011). Darwinians, communitarians, and missionaries: The role of founder identity in entrepreneurship. Academy of Management Journal, 54(5), 935-957.

Fini, R., Fu, K., Mathisen, M. T., Rasmussen, E., \& Wright, M. (2017). Institutional determinants of university spin-off quantity and quality: a longitudinal, multilevel, cross-country study. Small Business Economics, 48(2), 361-391.

Fini, R., Rasmussen, E., Siegel, D., \& Wiklund, J. (2018). Rethinking the commercialization of public science: From entrepreneurial outcomes to societal impacts. Academy of Management Perspectives, 32(1), 4-20.

Fisher, G., Kotha, S., \& Lahiri, A. (2016). Changing with the times: An integrated view of identity, legitimacy, and new venture life cycles. Academy of Management Review, 41(3), 383-409.

Giraudo, E., Giudici, G., \& Grilli, L. (2019). Entrepreneurship policy and the financing of young innovative companies: Evidence from the Italian Startup Act. Research Policy, 48(9), 103801.

Grilli, L. (2014). High-tech entrepreneurship in Europe: A heuristic firm growth model and three “(un-) easy pieces” for policy-making. Industry and Innovation, 21(4), 267-284.

Grilli, L., Jensen, P., Murtinu, S., Park, D.H. (2020). A close look at the contingencies of founders' effect on venture performance. Industrial and Corporate Change, forthcoming.

Grilli, L., \& Mariotti, S. (2006). Politiche per l'innovazione e cambiamento strutturale in Italia. L'Industria, 27(2), 365-396.

Grilli, L., \& Murtinu, S. (2014). Government, venture capital and the growth of European high-tech entrepreneurial firms. Research Policy, 43(9), 1523-1543.

Grimaldi, R., Kenney, M., Siegel, D. S., \& Wright, M. (2011). 30 years after Bayh-Dole: Reassessing academic entrepreneurship. Research policy, 40(8), 1045-1057. 
Guerrero, M., \& Urbano, D. (2019). Effectiveness of technology transfer policies and legislation in fostering entrepreneurial innovations across continents: an overview. The Journal of Technology Transfer, 44(5), 1347-1366.

Heirman, A., \& Clarysse, B. (2004). How and why do research-based start-ups differ at founding? A resource-based configurational perspective. The Journal of Technology Transfer, 29(3-4), 247-268.

Hahn, D., Minola, T., Bosio, G., \& Cassia, L. (2019a). The impact of entrepreneurship education on university students' entrepreneurial skills: a family embeddedness perspective. Small Business Economics, 1-26.

Hahn, D., Minola, T., \& Eddleston, K. A. (2019b). How do Scientists Contribute to the Performance of Innovative Start-ups? An Imprinting Perspective on Open Innovation. Journal of Management Studies, 56(5), 895-928.

Henrekson, M., \& Sanandaji, T. (2019). Measuring Entrepreneurship: Do Established Metrics Capture High-Impact Schumpeterian Entrepreneurship?. Entrepreneurship Theory and Practice, forthcoming.

Hottenrott, H., \& Richstein, R. (2020). Start-up subsidies: Does the policy instrument matter?. Research Policy, 49(1), 103888.

Hyytinen, A., Pajarinen, M., \& Rouvinen, P. (2015). Does innovativeness reduce startup survival rates?. Journal of Business Venturing, 30(4), 564-581.

Jain, S., George, G., \& Maltarich, M. (2009). Academics or entrepreneurs? Investigating role identity modification of university scientists involved in commercialization activity. Research Policy, 38(6), 922-935.

Jones, M. V., Coviello, N., \& Tang, Y. K. (2011). International entrepreneurship research (19892009): a domain ontology and thematic analysis. Journal of Business Venturing, 26(6), 632659.

Kazanjian, R. K. (1988). Relation of dominant problems to stages of growth in technology-based new ventures. Academy of Management Journal, 31(2), 257-279.

Kivimaa, P., \& Kern, F. (2016). Creative destruction or mere niche support? Innovation policy mixes for sustainability transitions. Research Policy, 45(1), 205-217.

Klepper, S., \& Sleeper, S. (2005). Entry by spinoffs. Management Science, 51(8), 1291-1306.

Kochenkova, A., Grimaldi, R., \& Munari, F. (2016). Public policy measures in support of knowledge transfer activities: a review of academic literature. The Journal of Technology Transfer, 41(3), 407-429.

Koryak, O., Lockett, A., Hayton, J., Nicolaou, N., \& Mole, K. (2018). Disentangling the antecedents of ambidexterity: Exploration and exploitation. Research Policy, 47(2), 413-427.

Lam, A. (2011). What motivates academic scientists to engage in research commercialization: 'Gold', 'ribbon'or 'puzzle'?. Research Policy, 40(10), 1354-1368.

Lerner, J. (2010). The future of public efforts to boost entrepreneurship and venture capital. Small Business Economics, 35(3), 255-264.

Lumpkin, G.T., Moss, T.W., Gras, D.M., Kato, S. and Amezcua, A.S. (2013). Entrepreneurial processes in social contexts: how are they different, if at all? Small Business Economics, 40(3), 761-783.

Malerba, F., \& McKelvey, M. (2018). Knowledge-intensive innovative entrepreneurship integrating Schumpeter, evolutionary economics, and innovation systems. Small Business Economics, 54(2), 503-522.

Marvel, M. R. (2013). Human Capital and Search-Based Discovery: A Study of High-Tech Entrepreneurship. Entrepreneurship Theory and Practice, 37(2), 403-419.

Markman, G. D., Waldron, T. L., Gianiodis, P. T., \& Espina, M. I. (2019). E Pluribus Unum: Impact Entrepreneurship as a Solution to Grand Challenges. Academy of Management Perspectives, 33(4), 371-382. 
Mathias, B. D., Williams, D. W., \& Smith, A. R. (2015). Entrepreneurial inception: The role of imprinting in entrepreneurial action. Journal of Business Venturing, 30(1), 11-28.

McKelvie, A., Brattström, A., \& Wennberg, K. (2017). How young firms achieve growth: reconciling the roles of growth motivation and innovative activities. Small Business Economics, 49(2), 273-293.

McMullen, J. S., \& Shepherd, D. A. (2006). Entrepreneurial action and the role of uncertainty in the theory of the entrepreneur. Academy of Management Review, 31(1), 132-152.

McMullen, J. S., \& Warnick, B. J. (2016). Should we require every new venture to be a hybrid organization?. Journal of Management Studies, 53(4), 630-662.

Merton, R. K. (1968). The Matthew effect in science: The reward and communication systems of science are considered. Science, 159(3810), 56-63.

Minola, T., Hahn, D., \& Cassia, L. (2019). The relationship between origin and performance of innovative start-ups: the role of technological knowledge at founding. Small Business Economics, forthcoming.

Moss, I. (2011). Start-up nation: An innovation story. Organisation for Economic Cooperation and Development. The OECD Observer, (285), 33.

Novotny, A., Rasmussen, E., Clausen, T. H., \& Wiklund, J. (2020). Introduction: Helping birds to fly: Introducing start-up incubation ecosystems. In Research Handbook on Start-Up Incubation Ecosystems. Edward Elgar Publishing.

Protogerou, A., Caloghirou, Y., \& Vonortas, N. S. (2017). Determinants of young firms' innovative performance: Empirical evidence from Europe. Research Policy, 46(7), 1312-1326.

Rasmussen, E. (2011). Understanding academic entrepreneurship: Exploring the emergence of university spin-off ventures using process theories. International Small Business Journal, 29(5), 448-471.

Rasmussen, E., Mosey, S., \& Wright, M. (2014). The influence of university departments on the evolution of entrepreneurial competencies in spin-off ventures. Research Policy, 43(1), 92106.

Rawhouser, H., Cummings, M., \& Newbert, S. L. (2019). Social impact measurement: Current approaches and future directions for social entrepreneurship research. Entrepreneurship Theory and Practice, 43(1), 82-115.

Rodrik, D. (1996). Coordination failures and government policy: A model with applications to East Asia and Eastern Europe. Journal of International Economics, 40(1-2), 1-22.

Shane, S. A. (2003). A general theory of entrepreneurship: The individual-opportunity nexus. Edward Elgar Publishing.

Shane, S. (2009). Why encouraging more people to become entrepreneurs is bad public policy. Small Business Economics, 33(2), 141-149.

Simsek, Z., Fox, B. C., \& Heavey, C. (2015). “What’s Past Is Prologue” A Framework, Review, and Future Directions for Organizational Research on Imprinting. Journal of Management, 41(1), 288-317.

Stam, E., van de Ven, A. (2019). Entrepreneurial ecosystem elements. Small Business Economics, forthcoming.

UNCTAD (2012). “Entrepreneurship Policy Framework and Implementation Guidance”. Geneva: United Nations Conference on Trade and Development.

van Winden, W., \& Carvalho, L. (2019). Intermediation in public procurement of innovation: How Amsterdam's startup-in-residence programme connects startups to urban challenges. Research Policy, 48(9), 103789.

Vohora, A., Wright, M., \& Lockett, A. (2004). Critical junctures in the development of university high-tech spinout companies. Research Policy, 33(1), 147-175.

Welch, X., Pavićević, S., Keil, T., \& Laamanen, T. (2019). The Pre-Deal Phase of Mergers and Acquisitions: A Review and Research Agenda. Journal of Management, 0149206319886908. 
Wilson, F. and Post, J.E. (2013). Business models for people, planet (\& profits): exploring the phenomena of social business, a market-based approach to social value creation. Small Business Economics, 40, 715-737.

Zahra, S. A., \& Wright, M. (2016). Understanding the social role of entrepreneurship. Journal of Management Studies, 53(4), 610-629. 
Table 1 - Descriptive summary of the 38 policies on innovative entrepreneurship (alphabetical order by country)

\begin{tabular}{|c|c|c|c|c|}
\hline Name of the policy & UNCTAD goals & Country & Policy objective & Approach \\
\hline $\begin{array}{c}\text { Argentina Startup \& } \\
\text { Talent Visa }\end{array}$ & $\begin{array}{l}\text { Network; Finance; } \\
\text { Immig. }\end{array}$ & Argentina & $\begin{array}{l}\text { To support talented foreign entrepreneurs to develop their innovative idea } \\
\text { in Argentina by granting a residence permit. The program also grants } \\
\text { access to funds, networks and incubators. }\end{array}$ & New firms \\
\hline $\begin{array}{c}\text { Argentina's } \\
\text { Entrepreneurs Act }\end{array}$ & Tax; Network & Argentina & $\begin{array}{l}\text { To generate ideal conditions to support innovative ideas in Argentina. It } \\
\text { includes quick company establishment (procedure can be finalized in } 24 \\
\text { hours, online) and facilitation in open a bank account. Tax benefits are } \\
\text { also guaranteed for investments. The program includes various financing } \\
\text { programs. Incubators and Accelerators are also included as beneficiaries. }\end{array}$ & New firms \\
\hline $\begin{array}{l}\text { International Relations } \\
\text { for Entrepreneurs and } \\
\qquad \text { SMEs }\end{array}$ & Network; Skill & Argentina & $\begin{array}{l}\text { To provide training, technical assistance and international reach to } \\
\text { facilitate and promote cooperation and connection of local entrepreneurs } \\
\text { with foreign peers, favoring a profitable exchange of information and } \\
\text { experiences. }\end{array}$ & Sector specific $^{\wedge}$ \\
\hline Entrepreneurs Clubs & Network; Skill & Argentina & $\begin{array}{l}\text { To provide financial support to open co-working spaces (including } \\
\text { offices, research laboratories and event spaces) that become incubators to } \\
\text { attract ideas, talent and promote the development of the area. }\end{array}$ & Partner specific \\
\hline $\begin{array}{l}\text { Argentine } \\
\text { Entrepreneurship } \\
\text { Academy }\end{array}$ & Network; Skill & Argentina & $\begin{array}{l}\text { To encourage the development of entrepreneurial skills by working } \\
\text { cooperation both physically (through conferences and meetings) and } \\
\text { virtually (through a platform where courses, seminars and other content } \\
\text { are available). }\end{array}$ & New firms \\
\hline Entrepreneurial Cities & $\begin{array}{c}\text { Network; Finance; } \\
\text { Skill }\end{array}$ & Argentina & $\begin{array}{l}\text { To develop a coordinated action plan (with public and private } \\
\text { institutions) that promotes entrepreneurship across Argentinian cities. } \\
\text { The three phases of the plan include: (1) study of the local entrepreneurial } \\
\text { ecosystem; (2) identification of critical issues and possible solutions; (3) } \\
\text { transformation of the ideas in Working Plan to be implemented within } 10 \\
\text { months with loans. }\end{array}$ & N/A \\
\hline $\begin{array}{c}\text { Early Stage Investor } \\
\text { Tax Incentives }\end{array}$ & Tax & Australia & $\begin{array}{l}\text { To provide tax incentives for early stage investors in start-ups (especially } \\
\text { angels investors) through non-refundable carry forward tax offset and } \\
\text { modified capital gains tax treatment. }\end{array}$ & $\mathrm{N} / \mathrm{A}$ \\
\hline
\end{tabular}




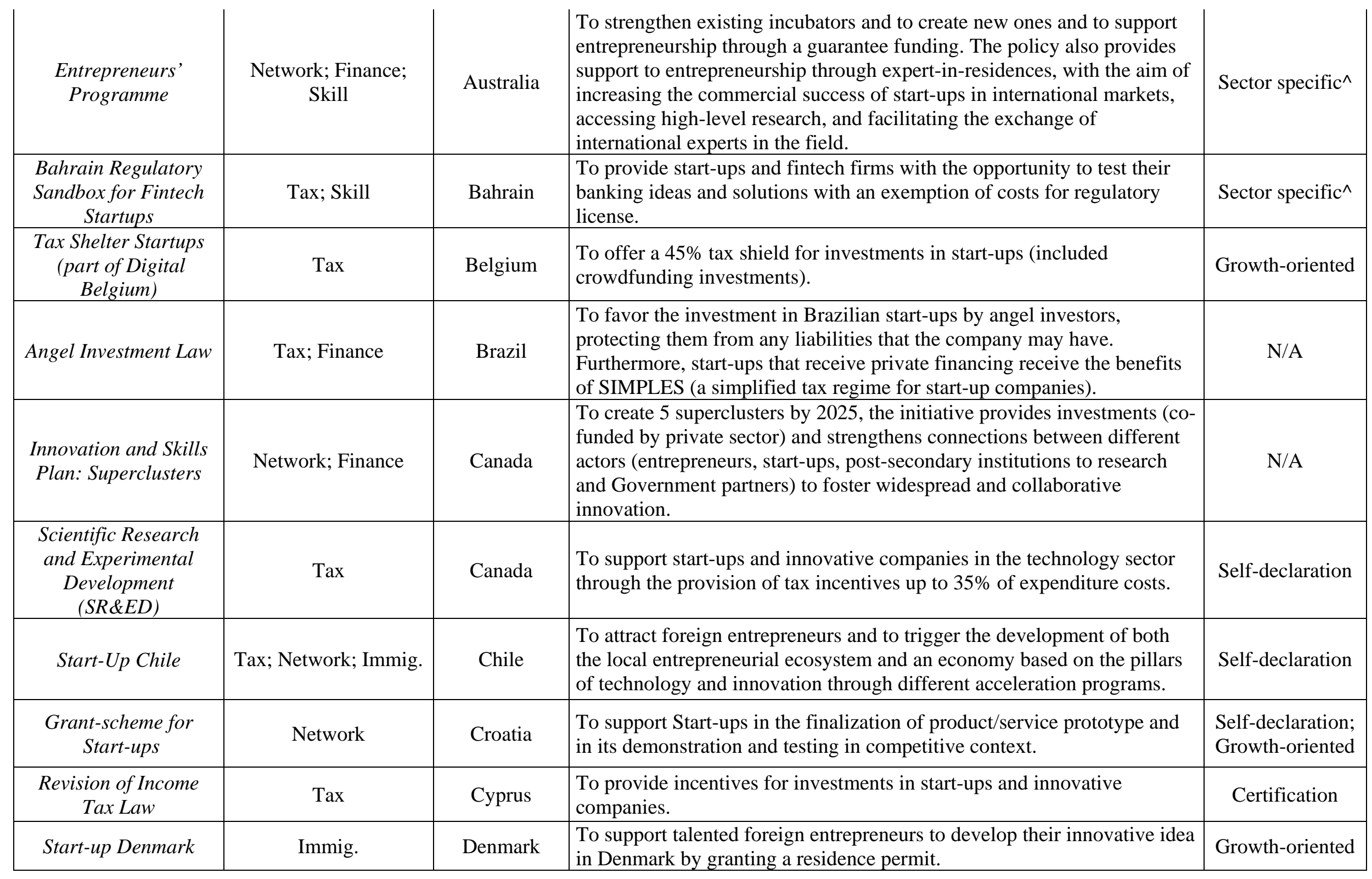




\begin{tabular}{|c|c|c|c|c|}
\hline \#HITSA2020 & Skill & Estonia & $\begin{array}{l}\text { To guarantee graduates the digital and ICT skills needed to start an } \\
\text { entrepreneurial activity. It provides innovative start-up courses with } \\
\text { successful founders as lecturers. }\end{array}$ & N/A \\
\hline Station F & $\begin{array}{l}\text { Network; Finance; } \\
\text { Immig. }\end{array}$ & France & $\begin{array}{l}\text { To support talented foreign entrepreneurs to develop their innovative idea } \\
\text { in France by granting a residence permit. The program also grants access } \\
\text { to funds, networks and partners, as well as incubators and hubs. }\end{array}$ & Growth-oriented \\
\hline Digital Hub Initiative & Network; Skill & Germany & $\begin{array}{l}\text { To strengthen the entrepreneurial ecosystem and the network between } \\
\text { established and early stage start-ups }\end{array}$ & New firms $\wedge$ \\
\hline Blue Growth & Network & Greece & To develop new innovative ideas regarding the navy industry. & Sector specific \\
\hline $\begin{array}{l}\text { The Innovation and } \\
\text { Technology Venture } \\
\text { Fund }\end{array}$ & Finance & Hong Kong & To co-invest in technology start-ups with private venture capital funds. & Sector specific \\
\hline Startup India & $\begin{array}{l}\text { Network; Finance; } \\
\text { Skill }\end{array}$ & India & $\begin{array}{l}\text { To encourage the creation of new incubators across India, guaranteeing } \\
\text { them financial support. To provide start-ups with the assistance, the } \\
\text { services and the information necessary to facilitate their development and } \\
\text { expansion. }\end{array}$ & $\begin{array}{l}\text { Self-declaration; } \\
\text { Partner specific }\end{array}$ \\
\hline TechIreland & Network & Ireland & $\begin{array}{l}\text { To support Irish companies in developing international outreach for their } \\
\text { technical knowledge. }\end{array}$ & Self-declaration^ \\
\hline $\begin{array}{l}\text { Clab (Contamination } \\
\text { Lab) }\end{array}$ & Network; Skill & Italy & $\begin{array}{l}\text { To expose university students, both from technical-scientific and } \\
\text { humanistic faculties, to a stimulating environment for the development of } \\
\text { innovative projects. }\end{array}$ & N/A \\
\hline Italian Startup Visa & Immig. & Italy & $\begin{array}{l}\text { To support non-EU entrepreneurs who want to establish an innovative } \\
\text { startup in Italy. Through this procedure, talents from all over the world } \\
\text { can obtain a 1-year self-employment visa for Italy, freely renewable at } \\
\text { expiration if the startup is up and running. }\end{array}$ & New firms \\
\hline Italian Startup Act & Tax; Finance; Skill & Italy & $\begin{array}{l}\text { To provide regulatory advantages, financial benefits, tailor-made labor } \\
\text { measures and other support instruments to innovative startups and } \\
\text { innovative SMEs. }\end{array}$ & Certification^^ \\
\hline $\begin{array}{l}\text { Global Acceleration } \\
\text { Program }\end{array}$ & Network; Skill & Malaysia & $\begin{array}{l}\text { To accelerate global start-ups to be investment-ready in } 4 \text { months. To } \\
\text { create a strong start-up community in the ASEAN (Association of } \\
\text { Southeast Asian Nations) area. }\end{array}$ & Growth-oriented \\
\hline $\begin{array}{l}\text { General Law of } \\
\text { Commercial } \\
\text { Companies (SAS) }\end{array}$ & Tax & Mexico & $\begin{array}{l}\text { To generate ideal conditions to support innovative ideas in Mexico. It } \\
\text { includes quick company establishment (procedure can be finalized in } 24 \\
\text { hours, online) at no costs. }\end{array}$ & New firms \\
\hline
\end{tabular}




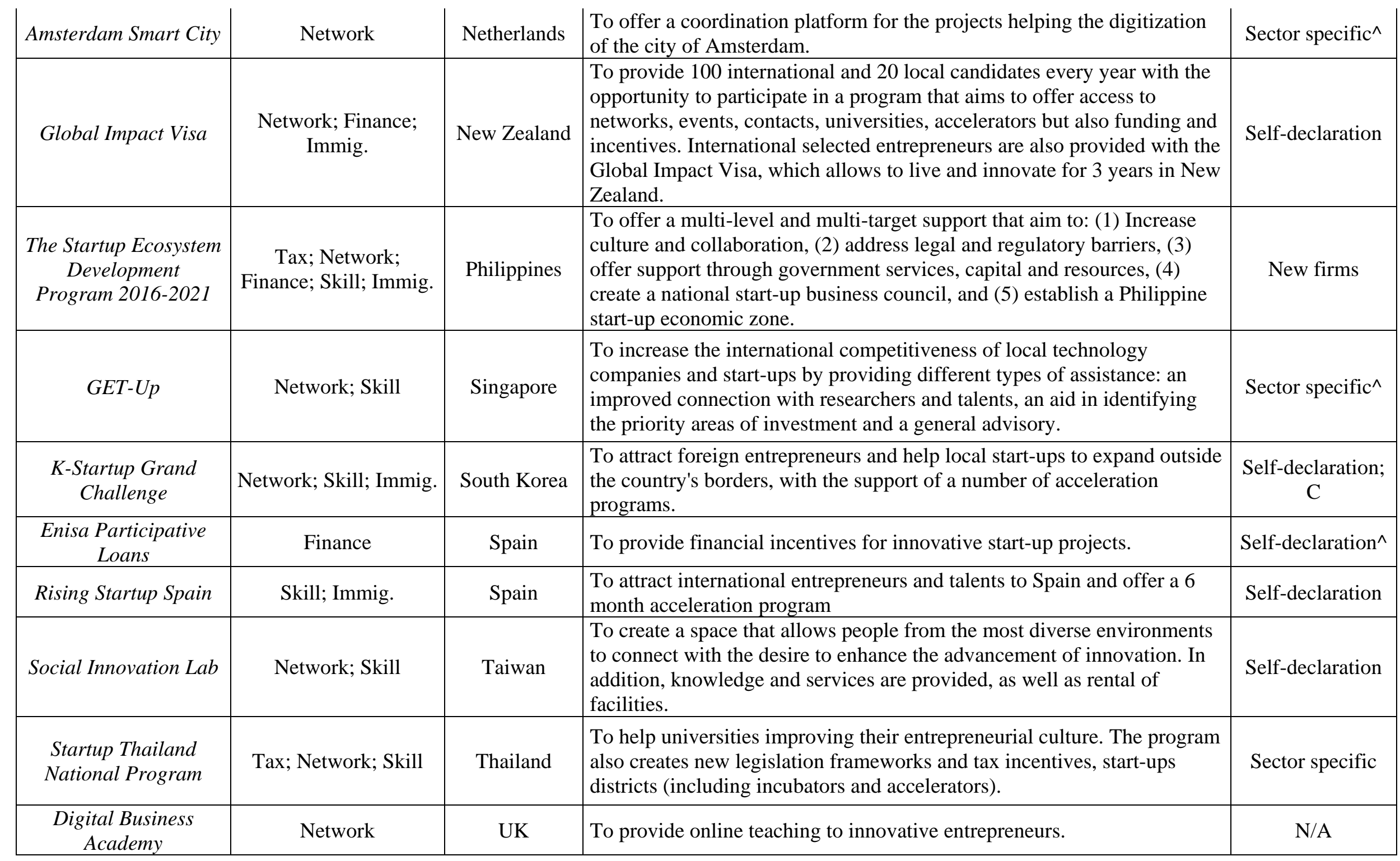

Legend: Tax = "Fiscal policy and tax Incentives"; Network = "Access to networks"; Finance = "Access to capital”; Skill = "Access to skills"; Immig. =

"Immigration". $\wedge=$ The measure also include SMEs 
Table 2 - Summary of contributions to the special issue

\begin{tabular}{|c|c|c|c|c|}
\hline Paper & Research Question & Dependent Variable & Independent Variable & Sample and definition of innovative start-up \\
\hline 545 & $\begin{array}{l}\text { What role do the } \\
\text { differences in } \\
\text { founders' } \\
\text { occupational } \\
\text { backgrounds play in } \\
\text { new venture } \\
\text { performance? }\end{array}$ & $\begin{array}{l}\text { Liquidity event; } \\
\text { patents; funding; exit. }\end{array}$ & $\begin{array}{l}\text { Academic vs. non- } \\
\text { academic background } \\
\text { (and type of). }\end{array}$ & $\begin{array}{l}\text { Sample of 1,723 start-ups from Crunchbase (tech-start-ups seeking } \\
\text { capital) considering only firms operating in biomedicine } \\
\text { (biotechnology and medical devices), which are particularly relevant } \\
\text { because both the production and the commercialization of new } \\
\text { technologies require a set of complex skills and expertise that } \\
\text { founders can acquire through their prior occupations. }\end{array}$ \\
\hline 579 & $\begin{array}{l}\text { What are the long- } \\
\text { term business and } \\
\text { innovation potential } \\
\text { of subsidized start- } \\
\text { ups out of } \\
\text { unemployment? }\end{array}$ & $\begin{array}{l}\text { Survival and labor } \\
\text { market status; } \\
\text { performance (income, } \\
\text { job creation, capital } \\
\text { constraints) and } \\
\text { innovation activities } \\
\text { (patenting and } \\
\text { protecting the } \\
\text { corporate identity). }\end{array}$ & $\begin{array}{l}\text { Formerly subsidized } \\
\text { businesses vs. regular } \\
\text { ones. }\end{array}$ & $\begin{array}{l}\text { The subsidized founders in the sample received the } \\
\text { "Gründungszuschuss" (start-up subsidy, SUS). }\end{array}$ \\
\hline 583 & $\begin{array}{l}\text { What are the drivers } \\
\text { of liquidity events } \\
\text { related to academic } \\
\text { spin-offs? }\end{array}$ & $\begin{array}{l}\text { Likelihood of a } \\
\text { liquidity event. }\end{array}$ & $\begin{array}{l}\text { Market- vs. technology- } \\
\text { search alliances. }\end{array}$ & $\begin{array}{l}\text { Sample of VC-backed ASOs that had developed and commercialized } \\
\text { technologies originating from British universities. In general, these } \\
\text { are technology-push firms that face the strategic option of competing } \\
\text { on the product market by developing products based on their } \\
\text { technology or entering the market for technology. }\end{array}$ \\
\hline 588 & $\begin{array}{l}\text { What is the effect of } \\
\text { the introduction of } \\
\text { university } \\
\text { regulations on }\end{array}$ & $\begin{array}{l}\text { Creation of academic } \\
\text { spin-offs (the decisions } \\
\text { of academic staff }\end{array}$ & $\begin{array}{l}\text { University regulations } \\
\text { in support of academic } \\
\text { entrepreneurship. }\end{array}$ & $\begin{array}{l}\text { Sample of } 611 \text { spin-off companies from } 64 \text { Italian Science, } \\
\text { Technology, Engineering, Mathematics and Medicine (STEMM) }\end{array}$ \\
\hline
\end{tabular}




\begin{tabular}{|c|c|c|c|c|}
\hline & \begin{tabular}{|l|} 
academic \\
entrepreneurship?
\end{tabular} & $\begin{array}{l}\text { regarding whether to } \\
\text { start a new venture). }\end{array}$ & & $\begin{array}{l}\text { universities between } 2002 \text { and } 2012 \text { (NOTE: the paper is at a } \\
\text { university-level, not at a firm level). }\end{array}$ \\
\hline 591 & $\begin{array}{l}\text { What are the design } \\
\text { features that are most } \\
\text { effective in } \\
\text { achieving the desired } \\
\text { outcomes of a GVC } \\
\text { policy? }\end{array}$ & $\begin{array}{l}\text { The probability that } \\
\text { GVC-backed } \\
\text { companies will receive } \\
\text { additional funds from } \\
\text { private venture capital } \\
\text { investors and, } \\
\text { ultimately, changes } \\
\text { will take place in their } \\
\text { growth and innovation } \\
\text { outcomes. }\end{array}$ & $\begin{array}{l}\text { Choices of location, } \\
\text { colocation, syndication } \\
\text { and industry focus of a } \\
\text { GVC program. }\end{array}$ & $\begin{array}{l}\text { Sample of European VC investments in which a Governmental } \\
\text { Venture Capital (GVC) fund provides financing in a first financing } \\
\text { round (1,230 investments by } 72 \text { GVCs) (NOTE: the paper is at an } \\
\text { investment-level, not at a firm level). }\end{array}$ \\
\hline 596 & $\begin{array}{l}\text { What are the effects } \\
\text { of related and } \\
\text { unrelated industry } \\
\text { variety in a start-up's } \\
\text { home location on the } \\
\text { start-up's } \\
\text { internationalization? }\end{array}$ & $\begin{array}{l}\text { Internationalization, in } \\
\text { terms of both the } \\
\text { likelihood of exporting } \\
\text { and persistence in } \\
\text { exporting. }\end{array}$ & $\begin{array}{l}\text { Related and unrelated } \\
\text { industry variety in a } \\
\text { start-up's home } \\
\text { location }\end{array}$ & $\begin{array}{l}\text { Start-ups from the manufacturing sector were selected from all the } \\
\text { registered firms and establishments in Sweden. }\end{array}$ \\
\hline 604 & $\begin{array}{l}\text { What are the } \\
\text { differences in } \\
\text { innovation } \\
\text { performance } \\
\text { between new and } \\
\text { older small firms? }\end{array}$ & $\begin{array}{l}\text { Innovation } \\
\text { effectiveness. }\end{array}$ & $\begin{array}{l}\text { R\&D investments, } \\
\text { external knowledge } \\
\text { sourcing and public } \\
\text { R\&D subsidies. }\end{array}$ & $\begin{array}{l}\text { SME and start-up data from the Spanish Technological Innovation } \\
\text { Panel database (PITEC) (based on CIS and representative of the } \\
\text { population of Spanish firms). Only innovative firms (i.e. that had } \\
\text { started to perform innovative activities) were selected. }\end{array}$ \\
\hline
\end{tabular}




\begin{tabular}{|c|c|c|c|c|}
\hline 610 & $\begin{array}{l}\text { Why do start-ups } \\
\text { differ in their } \\
\text { responses to } \\
\text { regulatory } \\
\text { constraints? }\end{array}$ & Start-up responses. & Temporal orientation. & $\begin{array}{l}11 \text { start-ups were selected on the basis of their quality and level of } \\
\text { engagement in their venture ideas on the drone application market (a } \\
\text { nascent market for an emerging technology characterized by strict } \\
\text { regulatory constraints on potential market applications). }\end{array}$ \\
\hline 730 & $\begin{array}{l}\text { What are the } \\
\text { conditions for policy } \\
\text { support } \\
\text { effectiveness, } \\
\text { especially for } \\
\text { innovative ventures? }\end{array}$ & $\begin{array}{l}\text { Growth milestones, net } \\
\text { of selection biases. }\end{array}$ & $\begin{array}{l}\text { Treatment (if so and } \\
\text { how many hours). }\end{array}$ & $\begin{array}{l}\text { 1,700 ventures that had enrolled in the Small Business Development } \\
\text { Center (SBDC), a government-sponsored program in the United } \\
\text { States that provides advisory services. The paper identifies } \\
\text { innovative firms as those that have prioritized innovation and } \\
\text { learning behavior. }\end{array}$ \\
\hline 735 & $\begin{array}{l}\text { To what extent do } \\
\text { young innovative } \\
\text { companies take } \\
\text { advantage of policy } \\
\text { support to enact } \\
\text { innovation } \\
\text { appropriation } \\
\text { mechanisms? }\end{array}$ & $\begin{array}{l}\text { The usage of formal } \\
\text { instruments (e.g., } \\
\text { intellectual property } \\
\text { rights) and informal } \\
\text { ones (e.g., secrecy, } \\
\text { lead time, access to } \\
\text { complementary assets) } \\
\text { to protect IP. }\end{array}$ & $\begin{array}{l}\text { Use of financial and } \\
\text { labor policy measures. }\end{array}$ & $\begin{array}{l}\text { More than 1,600 Italian Young Innovative Companies (YICs) } \\
\text { founded as a result of the Italian Startup Act (policy-based } \\
\text { definition: IPR, R\&D and human capital), which grants the } \\
\text { innovative start-up status on satisfaction of one of the following } \\
\text { requirements: R\&D expenditure level at least at } 15 \% \text { of costs or } \\
\text { turnover, qualified human capital, the possession of intellectual } \\
\text { property rights from a broad and inclusive range. }\end{array}$ \\
\hline 795 & $\begin{array}{l}\text { Are start-ups that } \\
\text { emphasize } \\
\text { environmental value } \\
\text { creation more than } \\
\text { economic value } \\
\text { creation ('greener } \\
\text { start-ups') more } \\
\text { innovative? }\end{array}$ & $\begin{array}{l}\text { Engagement in product } \\
\text { and process } \\
\text { innovations. }\end{array}$ & $\begin{array}{l}\text { Private wealth } \\
\text { generation vs. } \\
\text { environmental gains. }\end{array}$ & $\begin{array}{l}\text { Evidence from 2,894 start-up entrepreneurs in } 30 \text { countries from the } \\
\text { Global Entrepreneurship Monitor (GEM). }\end{array}$ \\
\hline
\end{tabular}


Table 3 - Process framework for innovative start-ups

\begin{tabular}{|c|c|c|c|c|}
\hline & Antecedents & Founding characteristics & Behavior & Outputs and impacts \\
\hline $\begin{array}{l}\text { Overarching } \\
\text { question }\end{array}$ & $\begin{array}{l}\text { Where do innovative start-ups } \\
\text { come from? }\end{array}$ & $\begin{array}{l}\text { What makes a start-up } \\
\text { innovative? }\end{array}$ & $\begin{array}{l}\text { What does an innovative start- } \\
\text { up do (differently)? }\end{array}$ & $\begin{array}{l}\text { What does an innovative start- } \\
\text { up achieve? }\end{array}$ \\
\hline $\begin{array}{l}\text { Theoretical } \\
\text { perspective(s) }\end{array}$ & $\begin{array}{l}\text { Knowledge spillover theory of } \\
\text { entrepreneurship; } \\
\text { psychological and cognitive } \\
\text { theories. }\end{array}$ & $\begin{array}{l}\text { Imprinting theory; social } \\
\text { exchange theory; (social) } \\
\text { identity theory. }\end{array}$ & $\begin{array}{l}\text { Resource-based view; } \\
\text { imprinting theory; behavioral } \\
\text { theory; (social) identity } \\
\text { theory. }\end{array}$ & $\begin{array}{l}\text { Identity theory; agency theory; } \\
\text { stewardship theory; behavioral } \\
\text { theory; evolutionary theory } \\
\text { and other process theories. }\end{array}$ \\
\hline $\begin{array}{l}\text { Nature of the } \\
\text { innovative start- } \\
\text { ups / Key aspects }\end{array}$ & $\begin{array}{l}\text { Originating from research } \\
\text { organizations (e.g., science- } \\
\text { based firms), corporate labs } \\
\text { (e.g., corporate spin-offs) or } \\
\text { user needs (i.e. user } \\
\text { innovations); embeddedness } \\
\text { in regional clusters; } \\
\text { relatedness with technological } \\
\text { changes and sectorial } \\
\text { dynamics; human capital and } \\
\text { originating a knowledge base. }\end{array}$ & $\begin{array}{l}\text { High levels of human capital } \\
\text { (skills and education); } \\
\text { complementary knowledge } \\
\text { and cohesion of a team; } \\
\text { knowledge and technology } \\
\text { base; affiliation with a } \\
\text { university or other knowledge- } \\
\text { intensive partners; identity and } \\
\text { partners. }\end{array}$ & $\begin{array}{l}\text { R\&D activities and } \\
\text { investments; collaboration, } \\
\text { alliances and external } \\
\text { knowledge integration; search } \\
\text { and ambidexterity; fund } \\
\text { raising and investments; } \\
\text { innovation appropriation; } \\
\text { internationalization (entry } \\
\text { strategies). }\end{array}$ & $\begin{array}{l}\text { Growth; internationalization } \\
\text { (sales); liquidity events, IPO } \\
\text { and exit; innovation; } \\
\text { economic impacts at firm, } \\
\text { regional and economy level; } \\
\text { societal impacts related to e.g., } \\
\text { health, wellbeing and } \\
\text { sustainability. }\end{array}$ \\
\hline Role of context(*) & $\begin{array}{l}\text { (I\&T) (entry conditions); (O) } \\
\text { (previous employment); (I\&P) } \\
\text { (informal institutions, such as } \\
\text { social norms, perceptions of } \\
\text { legitimacy and social } \\
\text { desirability; formal } \\
\text { institutions, such as regulation } \\
\text { of entry, rule of law); (S) } \\
\text { (family and peers). }\end{array}$ & $\begin{array}{l}\text { (I\&T) (technological aspects } \\
\text { and attributes); (O) } \\
\text { (experience, knowledge and } \\
\text { skills); (I\&P) (informal } \\
\text { institutions, such as social } \\
\text { norms; formal institutions, } \\
\text { such as property protection } \\
\text { and regulatory constraints); } \\
\text { (S) ( entrepreneur networks). }\end{array}$ & $\begin{array}{l}\text { (I\&T) (innovation and product } \\
\text { design); (O) (culture, } \\
\text { practices, experience, } \\
\text { knowledge and skill); (I\&P) } \\
\text { (informal institutions, such as } \\
\text { perceptions of legitimacy; } \\
\text { formal institutions, such as } \\
\text { rules of law); (S) (trading } \\
\text { partners, financiers, and } \\
\text { incumbent firms). }\end{array}$ & $\begin{array}{l}\text { (I\&T) (technology platforms); } \\
\text { (O) (culture, practices, } \\
\text { experience, knowledge and } \\
\text { skills); (I\&P) (informal } \\
\text { institutions, such as social } \\
\text { norms and social desirability; } \\
\text { formal institutions, such as } \\
\text { competition with former } \\
\text { employers and venture } \\
\text { capital); (S) (business and } \\
\text { governmental partners). }\end{array}$ \\
\hline $\begin{array}{l}\text { Papers in the } \\
\text { Special Issue }\end{array}$ & \#545, \#579, \#588, \#610. & \#579, \#583, \#735, \#795. & $\begin{array}{l}\text { \#583, \#591, \#596, \#604, \#610, } \\
\text { \#730, \#735. }\end{array}$ & \#545, \#579, \#583, \#795. \\
\hline
\end{tabular}




\begin{tabular}{|l|l|l|l|}
\hline $\begin{array}{l}\text { Examples of policy } \\
\text { initiatives }\end{array}$ & $\begin{array}{l}\text { Education and training } \\
\text { programs; business plan } \\
\text { competitions, support for } \\
\text { entrepreneurial team creation; } \\
\text { technology transfer offices, } \\
\text { IPR legislation. }\end{array}$ & $\begin{array}{l}\text { Start-up grants; seed capital; } \\
\text { advisory and coaching; } \\
\text { technology transfer initiatives; } \\
\text { attraction of foreign } \\
\text { entrepreneurs. }\end{array}$ & $\begin{array}{l}\text { Innovation grants and } \\
\text { financial measures (both direct } \\
\text { and indirect); incubators and } \\
\text { accelerators; stimuli for } \\
\text { external knowledge sourcing; } \\
\text { advisory and coaching; } \\
\text { removal of labor market } \\
\text { oriented policies (e.g., } \\
\text { environmental and } \\
\text { sustainability transition); } \\
\text { facilitated public procurement } \\
\text { schemes for start-ups. }\end{array}$ \\
\hline
\end{tabular}

Legend: $(*)(I \& T)$ industry and technological contexts; $(O)$ organizational contexts; (I\&P) institutional and policy contexts (formal and informal institutions); (S) social contexts (based on Autio et al., 2014).

Table 4 - Summary of future directions for research and policy

\begin{tabular}{|c|c|c|c|c|}
\hline & Antecedents & Founding characteristics & Behavior & Outputs and impacts \\
\hline $\begin{array}{l}\text { Development } \\
\text { process }\end{array}$ & $\begin{array}{l}\text { What is the effect of the growing } \\
\text { diffusion of entrepreneurship } \\
\text { education and new teaching } \\
\text { pedagogies on founders' human } \\
\text { capital? When does student } \\
\text { entrepreneurship prompt } \\
\text { innovative start-ups? How does } \\
\text { the strategic management process } \\
\text { of a university affect the rate and } \\
\text { quality of innovative start-ups? } \\
\text { How are the patterns of push } \\
\text { (e.g., digitalization) and pull } \\
\text { factors (e.g., new healthcare } \\
\text { needs and sustainability goals) } \\
\text { affecting the entry of innovative } \\
\text { start-ups? }\end{array}$ & $\begin{array}{l}\text { What are the optimal } \\
\text { combinations of different } \\
\text { founders' background in the } \\
\text { founding teams? How to } \\
\text { assess the complementarities } \\
\text { and effectiveness of a team? } \\
\text { Is there a female } \\
\text { underrepresentation problem } \\
\text { in the founding teams of } \\
\text { innovative start-ups? To what } \\
\text { extent is the family } \\
\text { embeddedness of founding } \\
\text { teams an asset rather than a } \\
\text { liability? }\end{array}$ & $\begin{array}{l}\text { What drives absorptive } \\
\text { capacity, learning and open } \\
\text { innovation in innovative } \\
\text { start-ups? How can the } \\
\text { interplay between } \\
\text { individual-, firm-, industry- } \\
\text { or regional-level factors } \\
\text { explain the formation, } \\
\text { persistence and evolution of } \\
\text { innovative behaviors (e.g., } \\
\text { internationalization, formal } \\
\text { and informal alliance } \\
\text { creation, new product } \\
\text { development) of start-ups? }\end{array}$ & $\begin{array}{l}\text { What governance forms do } \\
\text { innovative start-ups take on } \\
\text { (e.g., independent start-ups, } \\
\text { family start-ups, academic or } \\
\text { corporate spin-offs, internal } \\
\text { corporate ventures) and what } \\
\text { are the implications on the } \\
\text { growth trajectories, } \\
\text { innovation strategies and } \\
\text { performances of such firms? } \\
\text { How do innovative start-ups } \\
\text { gain legitimacy within an } \\
\text { industry? To what extent do } \\
\text { the firm-level economic } \\
\text { performance and the broader } \\
\text { societal impact of innovative } \\
\text { start-ups overlap? }\end{array}$ \\
\hline $\begin{array}{l}\text { Contextual } \\
\text { influence }\end{array}$ & $\begin{array}{l}\text { How do the mechanisms and } \\
\text { processes that explain the } \\
\text { contextual (e.g., social, }\end{array}$ & $\begin{array}{l}\text { How is the goal setting } \\
\text { process of innovative start- } \\
\text { ups embedded in the }\end{array}$ & $\begin{array}{l}\text { How do the mechanisms and } \\
\text { processes that explain the } \\
\text { contextual (e.g., social, }\end{array}$ & $\begin{array}{l}\text { How do the mechanisms and } \\
\text { processes that explain the } \\
\text { contextual (e.g., social, }\end{array}$ \\
\hline
\end{tabular}




\begin{tabular}{|c|c|c|c|c|}
\hline & $\begin{array}{l}\text { institutional, technology, policy, } \\
\text { regional) influences on the entry } \\
\text { of innovative start-ups differ from } \\
\text { non-innovative start-ups? How } \\
\text { can nuanced policy interventions } \\
\text { account for the determinants of } \\
\text { performance differences of } \\
\text { innovative start-ups across } \\
\text { distinct institutional } \\
\text { environments? }\end{array}$ & $\begin{array}{l}\text { founders' background, team } \\
\text { dynamics, as well as in the } \\
\text { social and institutional } \\
\text { context (e.g., family, } \\
\text { university)? What labor } \\
\text { market policy interventions } \\
\text { can help make innovative } \\
\text { start-ups more attractive to } \\
\text { employees? What constitutes } \\
\text { a well-functioning ecosystem } \\
\text { for the creation of innovative } \\
\text { start-ups and how can such } \\
\text { ecosystems be nurtured by } \\
\text { policy initiatives? }\end{array}$ & $\begin{array}{l}\text { institutional, technology, } \\
\text { policy, regional) influences } \\
\text { on the development of } \\
\text { innovative start-ups differ } \\
\text { from non-innovative start- } \\
\text { ups? How are behavioral } \\
\text { factors (i.e., values, } \\
\text { normative and cognitive } \\
\text { bases) of innovative start- } \\
\text { ups affected by contextual } \\
\text { factors? How do start-ups } \\
\text { respond to regulatory } \\
\text { constraints and changes? } \\
\text { What are the effects of } \\
\text { industry focus on policy } \\
\text { interventions? }\end{array}$ & $\begin{array}{l}\text { institutional, technology, } \\
\text { policy, regional) influences } \\
\text { on the exit of innovative start- } \\
\text { ups differ from non- } \\
\text { innovative start-ups? When } \\
\text { should public interventions } \\
\text { prefer indirect forms of } \\
\text { support rather than adopting a } \\
\text { 'hands-on-approach'? How } \\
\text { does the societal impact of } \\
\text { innovative start-ups differ } \\
\text { depending on the spatial } \\
\text { context? What are the ethical } \\
\text { issues related to the impact } \\
\text { created by innovative start- } \\
\text { ups? }\end{array}$ \\
\hline $\begin{array}{l}\text { Methodological } \\
\text { and measurement } \\
\text { issues }\end{array}$ & $\begin{array}{l}\text { How can embeddedness and the } \\
\text { position of innovative start-ups in } \\
\text { innovation or entrepreneurship } \\
\text { ecosystems be assessed? What is } \\
\text { the potential of matching } \\
\text { individual- and firm-level public } \\
\text { dataset in explaining the entry of } \\
\text { innovative start-ups? }\end{array}$ & $\begin{array}{l}\text { How do founding team } \\
\text { dynamics (e.g., the exit/entry } \\
\text { of members) affect the } \\
\text { innovativeness of start-ups? } \\
\text { Can alliances be used for a } \\
\text { fuller assessment of a start- } \\
\text { up's innovation potential? } \\
\text { What are the potential } \\
\text { benefits of long-term } \\
\text { monitoring of innovative } \\
\text { start-ups? }\end{array}$ & $\begin{array}{l}\text { How can different strategic } \\
\text { behaviors in different } \\
\text { technology sectors be } \\
\text { categorized and properly } \\
\text { measured beyond the } \\
\text { consolidated (often } \\
\text { dichotomous) classifications } \\
\text { (e.g., exploration vs. } \\
\text { exploitation)? }\end{array}$ & $\begin{array}{l}\text { How can success and } \\
\text { performance be } \\
\text { conceptualized to take into } \\
\text { account the very nature and } \\
\text { heterogeneity of innovative } \\
\text { start-ups? Are traditional } \\
\text { performance indicators (still) } \\
\text { adequate? How can societal } \\
\text { impacts be measured? How } \\
\text { do innovative start-ups } \\
\text { contribute to technological } \\
\text { trajectories within and across } \\
\text { industries? How is it possible } \\
\text { to assess the strategic } \\
\text { positioning of innovative } \\
\text { start-ups on nascent markets? }\end{array}$ \\
\hline
\end{tabular}

